\title{
Politik Kooptasi Karaeng Terhadap Hak Pilih Buruh Tani Pada Pilkada Serentak Tahun 2015 Di Kabupaten Bulukumba
}

\author{
Yuliana, Syarifuddin Jurdi, Fajar \\ Program Studi Ilmu Politik UIN Alauddin Makassar
}

\begin{abstract}
Abstrak
Studi ini membahas tentang politik kooptasi Karaeng terhadap hak pilih Buruh Tani pada Pilkada Serentak tahun 2015 di Desa Bontomacinna Kec. Gantarang Kab. Bulukumba. Jenis penelitian ini adalah penelitian kualitatif dengan pendekatan deskriptif yang berusaha menggambarkan, memahami, dan menafsirkan makna suatu peristiwa tingkah laku manusia. Penelitian ini menggunakan teori Patron-Klien untuk memahami Politik Kooptasi yang sedang berlangsung di Bulukumba. Karaeng yang berkuasa dalam kepemilikan lahan pertanian membutuhkan Buruh Tani untuk menggarap sawahnya dan sebaliknya Buruh Tani membutuhkan pekerjaan sebagai mata pencahariannya. Relasi yang terbangun diantara dua aktor tersebut melahirkan pengooptasian hak pilih para Buruh Tani.
\end{abstract}

Kata Kunci :

Politik Kooptasi, Karaeng, Buruh Tani, Potron-Klien, Pilkada Serentak 2015.

\section{PENDAHULUAN}

Studi ini membahas tentang politik kooptasi Karaeng terhadap hak pilih Buruh Tani pada Pilkada Serentak tahun 2015 di Desa Bontomacinna Kecamatan Gantarang Kabupaten Bulukumba. Penelitian ini mengkaji tentang keberadaan Karaeng sebagai pemilik lahan pertanian dan menggunakan lahannya sebagai alat kerjasama dan pengooptasian (perampasan) hak pilih Buruh Tani selama proses Pilkada Serentak tahun 2015 berlangsung di Bulukumba.

Kebanyakan Karaeng di Sulawesi Selatan merupakan pemilik lahan pertaniaan yang luas. Dengan kepemilikan ini, menyebabkan keberadaan Karaeng sangat berpengaruh bagi masyarakat karena adanya ketergantungan atas akses lahan. Sebagaimana yang terjadi di Kec. Gantarang, para Buruh Tani sangat bergantung pada kesempatankesempatan yang disediakan oleh Karaeng.

Pasca Orde Baru, ketika proses demokratisasi sedang berlangsung di ranah lokal, terdapat perubahan-perubahan yang memungkinkan para Karaeng kembali tampil dalam panggung politik lokal. ${ }^{1}$ Adanya kesempatan politik yang terbuka

\footnotetext{
1 Juanda Nawawi, "Strategi Kelompok Bangsawan Era Pemilihan Kepala Daerah Secara Langsung Oleh Rakyat Di Eks
}

menyebabkan mereka mencoba mendefinisikan ulang posisi mereka dalam struktur sosial masyarakat yang ada. Sehingga instrumen demokrasi di tingkat lokal seperti Pilkada dimanfaatkan oleh Karaeng untuk mendapatkan kekuasaan agar tetap survive. Hal ini dapat dilihat dengan banyaknya Karaeng yang mendapatkan posisi strategis baik dalam struktur pemerintahan maupun kepengurusan partai politik. ${ }^{2}$

Di Bulukumba, untuk memaksakan kehendak para Karaeng, mereka mengkooptasi hak pilih Buruh Tani yang memiliki ketergantungan kepada Karaeng. Ketergantungan Buruh Tani dikonversi menjadi keuntungan politik secara elektoral yang sejalan dengan pilihan politik Karaeng.

Pilkada Serentak tahun 2015 menandakan bagaimana politik kooptasi itu bekerja di Desa Bontomacinna Kec.Gantarang Kab.Bulukumba. Di mana para Buruh Tani tidak menggunakan hak pilihnya secara bebas karena mengikuti pilihan politik Karaeng. Ini disebabkan karena Buruh Tani memiliki ketergantungan pekerjaan yang selama ini

Kesultanan Buton 2014", Jurnal Analisis, Vol 3 No 3 (Desember 2014), h. 176.

${ }^{2}$ HaboddinMuhtar, "Karaeng Dalam Pusaran Politik Studi Kasus Di KabupatenJeneponto", Skripsi (Yogyakarta: Fakultas Ilmu Sosial Dan Ilmu Politik, Universitas Gajah Mada, 2009), h.2. 
disediakan oleh Karaeng. Sebagaimana kita ketahui, Karaeng di Bulukumba memiliki lahan persawahan yang luas sekaligus dijadikan alat barter untuk mendapatkan suara dalam pemilihan bupati.

Kemenangan A. Sukri Sappewali yang berpasangan dengan Tommi Satria pada Pilkada Serentak tahun 2015 dapat dipahami sebagai kemenangan Karaeng di Bulukumba. Keberadaan Karaeng di Bulukumba berawal dari keturunan dari Puang Mappamadeng, bapak dari Andi Sultan Dg. Raja, salah seorang cendekia atau tokoh penggerak dan pejuang kemerdekaan di Kec. Gantarang Kab. Bulukumba. Sementara itu A. Sukri Sappewali jika dilacak garis darahnya merupakan keturunan dari A.Sultan Dg.Raja.

Berdasarkan uraian di atas, maka studi ini bertujuan untuk menjawab pertanyaan umum bagaimana politik kooptasi Karaeng terhadap hak pilih Buruh Tani pada Pilkada Serentak tahun 2015 di Desa Bontomacinna Kec. Gantarang Kab. Bulukumba?

\section{KAJIAN PUSTAKA}

Sebelum menjelaskan lebih jauh bagaimana politik kooptasi berlangsung di Bulukumba, berikut ini dipaparkan studi-studi terdahulu yang dapat membantu dalam memetakan hal-hal apa yang sudah dan belum dibidik oleh peneliti sebelumnya.

Ade Setiawan menulis tentang "Gerakan Serikat Buruh Dengan Penolakan Batasan Hak Pilih (Studi Serikat Buruh Di Kabupaten Gresik Tahun 2011)”. Ade Setiawan menjelaskan bahwa buruh pada saat ini di anggap oleh kebanyakan orang sama dengan pekerja, padahal dari dasar pengertiannya buruh berbeda dengan pekerja. Buruh sendiri memberikan pengaruh yang besar dan baik dalam hal ekonomi maupun politik. Di bidang ekonomi buruh adalah unsur penggerak langsung perekonomian, karena tanpa adanya buruh maka pekerjaan seperti di pabrik dan perkebunan tidak akan berjalan dengan baik. Kontribusi mereka dibidang ekonomi terkadang tidak selaras dengan akses dan kebebasan yang diperoleh dibidang politik. Keterbatasan akses dan kebebasan Buruh menyebabkan hak pilihnya dibatasi. ${ }^{3}$

\footnotetext{
3 Ade Setiawan, " Gerakan Serikat Buruh Dengan Penolakan Batasan Hak Pilih (Studi Serikat Buruh Di Kabupaten Gresik Tahun 2011)", Skripsi (Gresik: fakultas Ilmu Sosial Dan Ilmu Politik, Universitas Gresik, 2014), h. 3.
}

Sementara itu, Taufik Ahmad menulis tentang "Genealogi Konflik Agraria Di Polongbangkeng Takalar Tahun 2014”. Taufik Ahmad menjelaskan tentang keterlibatan Karaeng dalam konflik agraria yang berlangsung di Takalar. Keterlibatan Karaeng dalam proses akuisisi lahan pertanian menjadi penyebab merenggangnya ikatan patron-klien. Lebih jauh dijelaskan bahwa "melonggarnya hubungan antara petani dan Karaeng dipertajam oleh aliansi baru Karaeng dengan militer dan korporasi selama Orde Baru di satu sisi. Di sisi lain petani di terpinggirkan oleh peran Karaeng dalam mendapatkan akses ekonomi, seperti pembatasan penggunan lahan kesempatan kerja di perusahaan." 4 Berbeda dengan Rustinsyah dalam tulisannya tentang "Hubungan Patron-Klien Di Kalangan Petani Desa Kebonrejo Tahun 2011”. Rustinsyah justru memperlihatkan hubungan yang sifatnya tidak konfliktual antara Patron dan Klien. Namun demikian, komersialisasi pertanian di sisi lain menyebabkan terjadinya ketimpangan sosial antara patron dan klien. ${ }^{5}$

Pembatasan akses secara politik para Buruh di Gresik dan hubungan Karaeng dengan Petani yang konfliktual di Takalar serta relasi yang timpang antara patron dan klien di Kebonrejo telah memberi kan gambaran bagaimana patronase bekerja.Namun hal yang membedakan antara penelitian ini dengan hasil tiga penelitian sebelumnya adalah absennya penjelasan tentang pola patronase yang dikonversi ke dalam keuntungan-keuntungan secara elektoral. Olehnya itu, untuk mengisi kekosongan yang ada maka penulis membidik bagaimana politik kooptasi bekerja di dalam ikatan patron-klien yang dikonversi ke dalam keuntungan secara elektoral.

\section{MEMBINCANG KONSEP PATRON-KLIEN}

Untuk memahami apa yang dimaksud dengan patron-klien, studi ini menggunakan istilah patron yang secara etimologi dapat diartikan sebagai seseorang yang memiliki kekuasaan (power), status, wewenang dan pengaruh. Sementara klien diartikan sebagai orang yang diperintah dan yang disuruh. ${ }^{6}$ Relasi keduanya merupakan aliansi yang

\footnotetext{
4 Taufik Ahmad,"Genealogi Konflik Agraria Di Polongbangkeng Takalar", Jurnal Masyarakat Indonesia, Vol 4 No 2 (Desember 2014), h. 145.

5 Rustinsyah, "Hubungan Patron-Klien Di Kalangan Petani Desa Kebonrejo Tahun 2011", Jurnal Patron-Klien, Vol 2 No 1 (April 2014).

6 Sunyoto Usman, Sosiologi; Sejarah, Teori dan Metodologi, (Yogyakarta: Center for Indonesian Research and Development [CIReD], 2004), h. 132.
} 
tidak sederajat, di mana kedudukan klien lebih rendah dan patron lebih tinggi.

Hubungan patron-klien pada masyarakat banyak ditemukan dengan istilah ajoareng dengan joa. Ajoareng adalah seseorang yang menjadi ikatan atau panutan. Dia ini bisa disebut seorang Punggawa, Aru, Karaeng ataupun pemuka masyarakat lainnya. Dia seorang pemimpin yang menjadi pusat atau poros kegiatan orang-orang di sekitarnya, yang kemauan serta kehendaknya diikuti dengan patuh oleh mereka yang menjadi pengikut setianya. Dalam masyarakat makassar ajoarangengatau patron tersebut adalah para Karaeng atau anakaraeng, danjoa-joanya disebut ana'-ana' atau tau-taunna (klien), yang dengan sukarela menjadi pengikut mereka merupakan keturunan dari pengikut-pengikut sebelumnya. Orang Sulawesi-Selatan sendiri menyebut hubungan antara Karaeng dengan Taunna sebagai pengikut. Relasi patron klien ini mampu bertahan di Sulawesi-Selatan dalam kurung waktu yang begitu lama, dimana berbagai perubahan sosial maupun politik telah banyak terjadi. ${ }^{7}$

Seorang Karaeng memang mempunyai kewajiban untuk memenuhi kebutuhan ana'-ana'nyaatau para pengikutnya. Dia memberi bantuan dengan menyediakan sawah atau tanah untuk digarap, bibit padi, kerbau untuk membajak. Seorang pengikut seringkali juga terlibat dalam perselisihan, karena telah melakukan pelanggaran atau karena dia merasa dirugikan oleh seseorang, maka dia akan melaporkan masalhnya tersebut kepada Karaeng. ${ }^{8}$

Persoalan perbedaan kedudukan antara Bangsawan dan orang biasa, atau pelapisan sosial yang berlaku dalam masyarakat Sulawesi-Selatan, perhatian perlu kita arahkan pada soal wujud sistem tersebut serta bagaimana orang menciptakannya. Artinya, kriteria apa yang dipakai oleh masyarakat Sulawesi-Selatan, terutama dalam masyarakat Makassar dan Bugis, kaum Bangsawan dikenal dengan gelar Karaeng atau aru'yang diartikan sebagai 'Raja' sedangkan kerabat-kerabatnya atau keturunannya desebut anakaraeng atau anakarung. ${ }^{9}$

Mengingat pembicaraan menyangkut masyarakat yang hidup dari bertani, maka perbedaan yang dicari tentunya yang berhubungan dengan soal

\footnotetext{
${ }^{7}$ Heddy Shri Ahimsa Putra, Patron Dan Klien Di Selawesi Selatan Sebuah Kajian Fungsional Struktural, (Yogyakarta: KEPEL PRESS, 2007), h. 12

${ }^{8}$ Heddy, h. 22.

${ }^{9}$ Heddy, h. 84
}

kepemilikan tanah. Penentuan tanah sebagai ukuran ternyata sesuai dengan pandangan masyarakat di sana mengenai apa yang dimaksud dengan kaya, seperti tampak dikalangan Karaeng. Dalam pemilikan tanah masyarakat Sulawesi-Selatan mengenal adanya tanah milik pribadi dan tanah komunal. Tanah yang tergolong milik pribadi misalnya sawah, kebun, ladang, dan kolam ikan, sedang tanah komunal yaitu hutan-hutan. ${ }^{10}$

Teori Patron-klien berkaitan dengan masalah yang diteliti oleh penulis yaitu politik kooptasi Karaeng terhadap hak pilih buruh tani pada pilkada serentak tahun 2015 di Desa Bontomacinna Kec. Gantarang Kab. Bulukumba. Dimana hubungan patron-klien sangat erat kaitannya dengan pengooptasian Karaeng terhadap hak pilih buruh tani yang dibatasi karena alasan kerjasama antara patronklien antara Karaeng dan buruh tani. Kerjasamanya yaitu hubungan timbal balik antara Karaeng dan buruh. Karaeng sebagai pemilik lahan pertanianmembutuhkan buruh tani untuk menggarap lahan pertaniannya, sedangkan buruh membutuhkan pekerjaan untuk memenuhi kehidupannya. Sehingga hubungan timbal balik inilah yang menjadi alasan Karaeng membatasi hak pilih para buruh.

\section{METODE PENELITIAN}

Penelitian ini dilaksanakan di Desa Bontomacinna Kec. Gantarang, Kab. Bulukumba. Adapun jenis penelitian yang digunakan adalah penelitian kualiatif yang mendeskripsikan peristiwa atau kejadian, perilaku atau orang atau suatu keadaan pada tempat tertentu secara rinci dan mendalam dalam bentuk narasi. Sementara itu pendekatan yang digunakan adalah pendekatan deskriptif yang berusaha menggambarkan, memahami, dan menafsirkan bagaimana politik kooptasi Karaeng terhadap hak pilih Buruh Tani pada Pilkada Serentak tahun 2015 di Desa Bontomacinna Kec. Gantarang Kab. Bulukumba.

Adapun sumber data dalam penelitian ini yakni data primer dan data sekunder. Data primer diperoleh peneliti di lapangan, melalui observasi dan wawancara dengan informan- informan kunci seperti Mulhaeriddin Djabbar (Kepala Desa), Najamuddin, A. Ratna, A. Nimrah, Abd. Hakim, Sahering, Uding, Abunawas, Hj.Bukke, dan H.A. Haerudding, yang dapat membantu memberikan informasi mengenai masalah yang sedang diteliti.

\footnotetext{
${ }^{10}$ Heddy, h.144.
} 
Sementara data sekunder dikumpulkan melalui telaah pustaka baik buku, jurnal, koran maupun sumber informasi lainnya yang erat kaitannya dengan masalah yang diteliti.

Setelah data-data diperoleh, kemudian diproses dengan cara mendeskripsikan fakta-fakta yang ditemukan lalu kemudian disusul dengan analisis, tidak semata-mata menguraikan, melainkan juga memberikan pemahaman dan penjelasan secukupnya. ${ }^{11}$ Selama penelitian berlangsung, peneliti telah melakukan proses pengabstraksian data karena lebih mudah dilakukan. Pada tahapan ini, singkatan, kategorisasi, memusatkan tema serta menentukan batas-batas permasalahan yang diajukan kepada para informan cukup membantu peneliti. Tahap selanjutnya penulis melakukan sajian data yakni suatu susunan informasi yang memungkinkan kesimpulan penelitian dapat dilakukan.

\section{PEMBAHASAN}

\section{Konteks Politik Kooptasi Karaeng}

Menurut Charles Horton Cooley, kooptasi berasal dari bahasa Inggris (Co-optation) yaitu suatu proses penerimaan unsur-unsur baru dalam kepemimpinan atau pelaksanaan politik dalam suatu organisasi. ${ }^{12}$

Kooptasi adalah pemilihan anggota baru dalam suatu organisasi. Mengooptasi adalah melakukan kooptasi. Terkooptasi adalah dapat dipilih. Pengooptasian adalah proses, cara, pembuatan, dan perampasan. ${ }^{13}$

Adapun hasil wawancara yang dilakukan oleh penulis terkait tentang konteks kooptasi politik Karaeng dengan informan bapak H. A. Haerudding selaku tokoh masyarakat di Desa Bontomacinna mengatakan bahwa:

"Kurangnya pendidikan politik pada buruh pun memicu terjadinya masalah politik di Desa Bontomacinna karena mereka hanya berfikir bagaimana mereka memiliki pekerjaan, mata pencaharian dan pendapatan. Sedangkan tentang politik mereka menganggap bahwa ketika sudah berpartisipasi pada pemilihan umum itu sudah bagus sehingga mereka mengorbankan hak

${ }^{11}$ Lisa Harrison, Metodologi Penelitian Politik, (Jakarta: Kencana, 2009), h. 105.

${ }^{12}$ Soerjono Soekanto, Sosiologi Suatu Pengantar, (Jakarta: Rajawali,1982), h. 5

13 http://kbbi.web.id/kooptasi.html, diakses pada tanggal 11/07/2017 Pukul 09.30 Wita. pilihnya di batasi oleh Karaeng tempat mereka bekerja. Tetapi ada juga yang sadar bahwa hak pilihnya dibatasi tapi mereka tetap mengikut karena tidak bisa melakukan perlawanan dan mereka terlibat hubungan kerjasama yang mengharuskan adanya imbalan kepada Karaeng karena sudah diberi pekerjaan. Tapi imbalannya pembatasan atau perampasan hak pilih dalam pemilihan Bupati 2015." 14

Dari hasil wawancara penulis dapat dikatakan bahwa saat ini pendidikan berpengaruh penting untuk masyarakat khusunya pendidikan mengenai politik untuk Buruh Tani. Karena ketertarikan masyarakat dalam memilih pemimpin hanya sebatas memilih saja dan imbalannya mereka tetap memiliki pekerjaan. Tidak memikirkan dampak yang diperoleh beberapa tahun yang akan datang. Kooptasi yang terjadi antara Karaeng dan Buruh Tani di Desa Bontomacinna merupakan praktik politik dengan usaha ke arah kerjasama yang dilakukan dengan menyepakati pemimpin yang akan ditunjuk untuk mengendalikan jalannya organisasi atau kelompok. Sebagaimana yang terjadi dengan hubungan kerjasama antara Karaeng sebagai pemilik lahan pertanian dan buruh tani, mereka tetap bekerjasama atau mempekerjakan buruh tani dilahannya dengan persyaratan ikut memilih calon Bupati yang didukung oleh Karaeng pada pemilihan Bupati Bulukumba tahun 2015. Dimana hak pilih buruh dibatasi oleh keberadaan Karaeng sebagai pemilik lahan pertanian (sawah).

Kaitanya yaitu hubungan kerjasama antara Karaeng dan buruh tani bukan hanya sebatas hubungan pemilik dan penggarap melainkan petani di tuntut mengerjakan apa yang diperintahkan oleh karang sebagai pemilik lahan, seperti pembatasan (kooptasi) hak pilih dalam pilkada serentak tahun 2015 di Desa Bontomacinna Kec. Gantarang Kab. Bulukumba. Bahkan buruh juga biasanya di perintah oleh Karaeng untuk mengerjakan pekerjaan yang tidak ada sangkut-pautnya dengan buruh tani seperti memperbaiki atap rumah yang Bocor, mengecat pagar, membersihkan halaman rumah, dan lain-lain. Intinya pekerjaan buruh tani tidak hanya sebagai buruh saja tetapi hubungan sosial. Buruh tidak melakukan penolakan karena mereka menganggap hal ini adalah hubungan timbal balik antara patro-klien.

${ }^{14}$ H. A. Haerudding, (52 Tahun, Tokoh Masyarakat), wawancara yang berlangsung pada hari Kamis, 30 Maret 2017, di kediaman Beliau di Desa Bontomacinna, Pukul 15.00 Wita. 
Karaeng menggunakan kekuasaannya sebagai pemilik lahan pertanian merupakan alat untuk mengkooptasi (membatasi) hak pilih para buruh tani di Desa Bontomacinna dalam pilkada serentak tahun 2015. Karena Karaeng menganggap bahwa yang memiliki lahan pertanian itu adalah mereka dan buruh tani membutuhkan pekerjaan sebagai penggarap di lahan pertanian Karaeng tersebut.

\section{Karaeng, Buruh Tani Dan Hubungan Patron- Klien}

Hubungan yang terjadi anatara Karaeng dan Buruh Tani dapat dikatakan hubungan patron klien meliputi hubungan timbal balik saling memberi dan menerima. Pemilik lahan dianggap lebih tinggi kedudukannya dari pada penyewah tanah dan penyewah tanah dianggap lebih tinggi dari pada buruh lepas, meskipun dari segi penghasilan mungkin tidak, masing-masing mewakili satu loncatan kuantum dalam kepercayaan terhadap subsistensi. ${ }^{15}$ Hal ini digambarkan oleh Scott sebagai moral ekonomi. Moral ekonomi petani didasarkan atas norma subsistensi dan norma. Dimana ketika seorang petani mengalami suatu keadaan yang menurut mereka dapat merugikan kelangsungan hidupnya, maka mereka akan menjual dan menggadai harta benda mereka. Hal ini disebabkan oleh moral subsistensi. ${ }^{16}$

Keberadaan Karaeng dan buruh tani berhubungan dengan Patron-klien karena dengan adanya hubungan kerjasama antara Karaeng sebagai pemilik lahan pertanian membutuhkan buruh tani untuk menggarap sawahnya dan sebaliknya buruh membutuhkan pekerjaan atau mata pencaharian untuk melanjutkan hidup. Hal ini tergambarkan dari keterangan salah satu informan kunci yang menjelaskan bagaimana pola patronase tersebut bekerja.

Adapun hasil wawancara yang dilakukan oleh penulis terkait tentang Karaeng dan buruh tani dan hubungannya dengan patron-klien mengenaiperan pemerintah melihat fenomena hubungan kerjasama buruh tani dan Karaeng dengan informan $\mathrm{H}$. A. Mulhaeriddin Djabbar, S.Ag ( H.A. Iccu') Kepala Desa Bontomacinna mengatakan bahwa:

"Saya sebagai kepala Desa melihat kerjasama antara keberadaan Karaeng sebagai pemilik lahan pertanian dan buruh tani yang yang terjalin di Desa Bontomacinna sekarang ini cukup baik karena masyarakat tidak penah

\footnotetext{
15 James C.Scott, Moral Ekonomi Petani Pergolakan Dan Subsistensi Di Asia Tenggara,(Jakarta:LP3ES, 1983), h. 69

${ }^{16}$ James, h. 57.
}

protes ke aparat Desa tentang hubungan kerjasama, dimana Karaeng sebagai pemilik lahan pertanian membutuhkan buruh yang bisa menggarap sawahnya dengan baik, agar hasil yang diperoleh sesuai dengan luasnya lahan yang dikerja buruh. Dan dalam memilih atau merekrut buruh tani di Desa Bontomacinna berbeda-beda, ada yang melihat dari kekeluargaan, mata pencaharian, dan keahlian. Aturan yang dikeluarkan pemilik lahan dalam menjalin kerjasama dengan buruh yaitu sistem bagi hasil dimana hasil panen dibagi dua. Dan mengenai proses penggarapan (passisi/pattaneng), pengadaan pupuk, bibit padi, dan pestisida di tanggung oleh para buruh tani, dan mengenai cara penggarapan sawah di desa ini bekerja sama dengan pertania (kelompok tani), karena untuk penanggulangan hama di persawahan pertanian menyediakan racun (pestisida) yang lebih murah, jadi para buruh tidak mengalami kendala besar dalam penggarpan sawah. Dan Alhamdullillah, tidak pernah terjadi gagal panen karena kesalahan dalam penggarapan, tetapi biasanya hanya karena bencana alam. sedangkan melihat fenomena pemilihan umum di Desa Bontomacinna antara batasan hak pilih kurang transparan karena yang saya lihat selama ini tidak ada protes dari para buruh sehingga kami aparat pemerintah menganggap bukan masalah yang cukup besar dan mengenai pemilihan kita sebagai aparat pemerintahanhanya menghimbau atau mengajak warga/masyarakat memilih yang terbaik sesuai hati nurani. Dan mengenai partisipasi buruh tani dalam pemilihan ada yang jadi pemilih biasa sampai tim sukses, tetapi kalau jadi tim sukses mereka rata-rata pendidikan mulai dari SMP- S1, yang jelaspaham mengenai aturan pemilihan umum." 17

Dari hasil wawancara penulis dapat dikatakan bahwa pada umumnya masyarakat desa memenuhi kebutuhan hidupnya dengan cara bertani, baik bertani dengan lahan sendiri maupun menggarap tanah orang lain. Namun demikian, penulis menemukan di lokasi penelitian bahwa kebanyakan petani tak bertanah karena itu menggantungkan hidupnya pada hasil garapan lahan yang dimiliki para pemilik tanah, dalam hal ini para Karaeng.

Ketiadaan lahan itulah membentuk relasi kerjasama antara Karaeng dan Buruh Tani. Bagi Karaeng, kerjasama demikian menguntungkan dan memudah kan dalam proses produksi. Ini disebabkan karena tenaga kerja merupakan satu-satunya faktor produksi yang relatif melimpah bagi kaum petani atau buruh tani. Oleh karena itu, Buruh Tani terpaksa melakukan kegiatan-kegiatan yang berat yaitu menjadi buruh demi memenuhi kebutuhan

${ }^{17}$ H. A. Mulhaeriddin Djabbar, S.Ag, (37 Tahun, Kepala Desa Bontomacinna), wawancara yang berlangsung pada hari Sabtu, 01 April 2017, di kediaman Beliau di Desa Bontomacinna, Pukul 16.30 Wita. 
mereka. Seperti keadaan petani pada masa sulit (paceklik), maka dalam hal ini Karaeng memberikan pertolongan terhadap petani dengan memberi pinjaman dan dapat dibayar ketika selesai panen.

Hubungan antara Karaeng dan buruh tani terdapat ketidak samaan pertukaran atau hubungan timbal balik yang menggambarkan perbedaan dalam kekuasaan, kekayaan, dan kedudukan. Dan ikatan antara patron klien tidak jauh beda dengan hubungan kerjasama Karaeng dan buruh tani untuk memperluas hubungan.

Adapun wawancara yang dilakukan oleh penulis terkait tentang Karaeng dan patron-klien mengenai kerjasama buruh tani dan Karaeng pemilik lahan pertanian dengan informan yakni bapak $\mathrm{H}$. A. Najamuddin. MBA mengatakan bahwa:

“ Kalau melihat keberadaan pemilik lahan di Desa Bontomacinna rata-rata memang dari kalangan Karaeng, Dan mereka tidak mengetahui bagaimana cara menggarap sawah, maka dari itu mereka bekerjasama dengan buruh tani yang ada di Desa ini. Dimana sebagaian besar mata pencahariannya mereka betulbetul petani penggarap. Dan mereka memiliki keahlian yang profesional dalam menggarap sawah. Kalau sistem bagi hasil yang digunakan para pemilik lahan yaitu hasil panen di bagi 2 maka sama-sama menguntungkan antara buruh tani dan Karaeng”. Saya merupakan salah satu Karaeng pemilik lahan yang mempekerjakan buruh tani di sawah karena saya tidak tahu bagaimana menggarap sawah jadi lebih baik bekerjasama dengan buruh tani, dan itu membantu perekonomian para buruh tani yang ada di Desa Bontomacinna.", 18

Pemilik tanah dianggap lebih tinggi kedudukannya dari pada Buruh tani sehingga Karaeng atau pemilik lahan pertanian lebih memilih hubungan kerjasama anatara Karaeng dan buruh tani yang sama-sama ada hubungan timbal baliknya dimana Karaeng membutuhkan buruh uutnuk menggarap sawahnya dan buruh membutuhkan pekerjaan sehingga terjadi hubungan kerjasama.

Adapun hasil wawancara yang dilakukan oleh peneliti mengenai kerjasama Karaeng pemilik lahan pertanian dan buruh tani, dengan informan yakni Dra. Hj. A. Ratna selaku Karaeng pemilik lahan pertanian di Desa Bontomacinna Mengatakan bahwa:

18 H. A. Najamuddin. MBA, (51 Tahun, Karaeng), wawancara yang berlangsung pada hari Minggu, 02 April 2017, di kediaman Beliau di Desa Bontomacinna, Pukul 15.00 Wita.
“ Sebagai pemilik lahan saya mempekerjakan 3 orang buruh tani sebagai penggarap sawah saya karena suamiku meninggalmi dan selama hidupnya juga tidak pernah kerja sawah tetap ji mempekerjakan buruh, jadi saya hanya meneruskan saja. Kalau bicara tentang bagaimana saya merekrut para buruh. Saya hanya memakai sistem kekeluargaan, kalau ada keluarga yang tidak mempunyai pekerjaan tetapi mampu menggarap sawah maka saya memberinya sawah untuk di garap dan hasilnya dibagi dua. Karena rata-rata yang bekerja sebagai buruh tani di lahan persawahan saya adalah keluarga biasannya saya memberi tunjangan hari raya berupa sembako. Supaya hubungan kerjasama tetap berjalan dengan baik. Tapi yang kurang sekarang itu pendistribusian hasil panen yang terbatas karena hanya di ambil atau dibeli oleh pedagang yang ada di Desa Bontomacinna itu pun pembayarannya tidak sekaligus tapi dicicil jadi biar pun buruh tani sudah panen mereka tetap kekurangan, mencukupi kebutuhannya. Jadi kita sebagai pemilik lahan biasa memberinya keringanan dengan memberikan pinjaman atau modal untuk menggarap sawah dan dibayar setelah uang panen dari pedagang diterima ". 19

Pada masa orde baru hubungan patron klien juga mengalami manifestasi yang berbeda. Terjadinya perubahan komposisi elite mengakibatkan sistem patronase tidak lagi berdasarkan faktor darah biru. Komposisi elit baru terdiri atas Bangsawan. Hal ini kemudian berdampak dalam sistem patron klien di masyarakat Sulawesi Selatan. wibawa Bangsawan yang memiliki latar belakang militer akan terangkat dimata masyarakat. Model patron klien kembali menjadi dasar dalam membangun kekuatan politik lokal. Pada pemilu 1999 partai politik bermunculan. Maraknya partai politik pada masa reformasi menjadi wadah bagi para patron untuk kembali membangun jaringan kliennya. Para bangsawan menjadi "politisi" dadakan dengan mengandalkan status sosial dan jaringan kliennya dibasis DaerahDaerah mereka. ${ }^{20}$

Adapun hasil wawancara yang dilakukan oleh peneliti terkait tentang Karaeng dan buruh tani relasi fungsional mengenai kerjasama Karaeng pemilik lahan pertanian dan buruh tani dangan informan yakni ibu $\mathrm{Hj}$. A. Nimrah, S.Pd Karaeng pemilik lahan pertanian mengatakan bahwa :

"Cara merekrut buruh tani yang bekerja di lahan sawah saya dilihat dari mata pencahariannya dan caranya selama ini menggarap sawah, kalau sudah sesuai

${ }^{19}$ H. A. Ratna, ( 56 Tahun, Karaeng), wawancara yang berlangsung pada hari Minggu, 02 April 2017, di kediaman Beliau di Desa Bontomacinna, Pukul 16.00 Wita.

20 Sitti Zuhro, Demokrasi Lokal Perubahan Dan Kesinambungan Nilai-Nilai Budaya Politik Loka Di Jawa Timur, Sumatera Barat, Sulawesi Selatan, (Yogyakarta: Ombak 2009). h 187. 
dengan program pertanian justru lebih bagus lagi, karena bisa dijamin juga hasil panennya pasti bagus. Di Desa Bontomacinna memang sistem bagi hasil panennya di bagi dua tapi pengadaan pupuk dan bibit ditanggung buruh tani sendiri. Dan melihat kerjasama antara Karaeng dan buruh tani itu sama-sama menguntungkan, sehingga sampai sekarang masing-masing terjalin hubungan kerjasama tersebut". ${ }^{21}$

\section{Hubungan Patron-Klien ke Kooptasi Politik}

Hubungan patronase antara Karaeng dengan Buruh Tani yang meluas, bukan hanya kerjasama dalam aspek tenaga kerja tetapi lebih jauh menyentuh pada aspek elektoral. Hal ini tergambarkan dari hasil wawancara penulis dengan salah satsu infoman kunci.

Adapun hasil wawancara yang dilakukan oleh penulis terkait tentang relasi patron klien ke kooptasi politik dengan informan Bapak Abd. Hakim, Buruh tani mengatakan bahwa:

“ Mata pencaharian saya dari dulu memang petani karena tidak sempatki sekolah tinggi, jadi buruh tani itu pekerjaan yang cocok karena tidak memerlukan ijazah. Jadi buruh tani yang dilihat carata menggarap sawah. kalau sudah sesuai dengan program pertanian Desa, sehingga Karaeng memberikan kesempatan atau pekerjaan untuk menggarap sawahnya dengan harapan hasil panennya sesuai dengan luas lahan yang dikerja.

Dan kalau tentang hak pilih ta sebagai buruh tani selama ini memang sudah dibatasi, karena mau tidak mau ikut ki sama yang ditempati kerja sawah, karena itu adalah imbalan kepada Karaeng karena memberi kita pekerjaan, dan kalau memilih ki dan bukan yang mereka dukung, tidak langsung jaki na berhentikan bekerja di sawahnya tapi jangan sampai beberapa bulan ke depan na gantikan ki dengan orang lain untuk menggarap sawahnya, Karena memang pada umumnya begitu hubungan kerjasama di Desa ini di sangkut pautkan sama politik (pemilihan umum). Dan Masalahnya juga mengenai sistem bagi hasil yang ada di Desa Bontomacinna hasil panen di bagi dua, tetapi pengadaan bibit, pupuk, dan pestisida di tanggung para buruh sendiri andaikan ditanggung buruh tapi kalau sudah panen dihitung bagi dua juga tidak apa-apa. Tetapi yang pemilik lahan tau itu berapa hasi panen itu yang dibagi dua contoh 50 karung masing-masing 25 karung, tapi belum terhitung pembelian bibit,pupuk, dan pestisida, itu yang selama ini yang di permasalahkan para buruh karena biaya penggarapan saat ini sudah mahal seperti bibit, pupuk, pestisida, dan lain-lain tapi biaya penggarapannya tidak dibagi dua dengan Karaeng

${ }^{21} \mathrm{Hj}$. A. Nimrah S. Pd, (44 Tahun,Karaeng), wawancara yang berlangsung pada hari Rabu, 05 April 2017, di kediaman Beliau di Desa Bontomacinna, Pukul 15.00 Wita. tetapi di tanggung oleh buruh tani, karena yang di tahu Karaeng itu hasil panen di bagi 2 (dua)", ${ }^{22}$

Sementara itu, Abu Nawas memberikan penjelasan yang tidak jauh beda dengan Abd. Hakim. Adapun hasil wawancara yang dilakukan oleh penulis dengan informan Abu Nawas, Buruh Tani mengatakan bahwa:

" Kalau Karaeng memilih Buruh Tani untuk menggarap sawahnya karena melihat dari ketelitian dari caranya buruh bekerja atau menggarap sawah. Semakin bagus carata bekerja dan hasil panennya juga bagus semakin lama juga bertahan bekerja. Tapi yang menjadi kendala biasana sistem bagi hasilny disaat gagal panen. Karena namanya juga kita bekerja dilahan orang jadi apabila terjadi kendala gagal panen kita tetap mebagi dua hasil panen. Tapi kalau batasan dalam pemilihan para petani pasti biasa bilang iga na pilih Bos e iyya tona ro idi di pilih.Mau tidak mau ikutki karena lahan sawahnya dikerja jangan sampai na tarik kembali, tidak adami mata pencaharianta na petani saja pekerjaan ta". ${ }^{23}$

\section{Karaeng dan Buruh Tani dalam Pilkada 2015}

Pada Pilkada yang dilakukan serentak pada tahun 2015 Sulawesi Selatan menunjukkan praktik perilaku politik patron klien. Ini terlihat khususnya, yang berlangsung di Kabupaten Bulukumba dimenangkan oleh pasangan A.Sukri Sappewali dan Tommy Satria yang merupakan Bupati keturunan Karaeng dari A. Sultan Dg. Raja dan A. Sappewali yang merupakan kakek dan bapak dari A. Syukri Sappewali. Dan hal ini menunjukkan masih kuatnya pengaruh kaum Bangsawan (Karaeng) di wilayah tersebut. Jumlah pendukung (klien) yang banyak menjadi faktor penentu kemenangan mereka dalam pemilihan kepala Daerah yang dilakukan secara langsung tersebut.

Karaeng membangun kroninya dengan mengangkat kaum kerabat untuk menduduki jabatan birokrasi yang strategis dan menguntungkan. Otonomi daerah juga dimanfaatkan, disisi lain kekuasaan kaum Karaeng tersebut diperkuat melalui anggota kerabat dan kroni dalam pemerintahan, dari tingkat Desa, Kabupaten, hingga Parlemen. ${ }^{24}$

${ }^{22}$ Abd. Hakim (45 Tahun, Buruh Tani), wawancara yang berlangsung pada hari Sabtu, 15 April 2017, di kediaman Beliau di Desa Bontomacinna, Pukul 16.00 Wita.

23 Abu Nawas (47 Tahun, Buruh Tani), wawancara yang berlangsung pada hari Senin, 17 April 2017, di Pabrik Padi di Desa Bontomacinna, Pukul 15.30 Wita.

${ }^{24}$ Andriani Saputri, "Patron Klien Antara Pemilik Lahan Dan Buruh Tani Studi Pada Desa Sipangan Bolon Kec. Girsang Bolon Kab. Simalungun", Skripsi, ( Medan: Jurusan Ilmu Sosial Politik, Fakultas Ilmu Sosial Dan Politik, 2015), hal. 112. 
Partisipasi masyarakat (buruh tani) dalam Pilkada Serentak 2015 tidak terlepas dari perilaku memilih masyarakat itu sendiri, namun ada beberapa faktor yang menyebabkan hak pilih para buruh dapat dibatasi oleh keberadaan Karaeng sebagai pemilik lahan yaitu berhubungan dengan mata pencaharian dan hubungan kerja sama (ptron-klien).

Adapun hasil wawancara yang dilakukan oleh penulis terkait tentang Karaeng dan buruh dalam pilkada 2015 mengenai asal- usul Karaeng dengan informan nenek $\mathrm{Hj}$. Bukke masyarakat biasa di Desa Bontomacinna mengatakan bahwa:

" Narekko Karaeng di carita pole dega assalenna di Desa Bontomacinna iya ro kuissengge Karaeng pole arajangeng Bone diaseng Petta Riu Karaeng loppo nomoro seddi' di kecamatan Gantarang. Narrekko masalah galung, paling loang galungna petta Riu di Gantarang. Mingka Na arengi' anaknna diaseng petta lulu. Petta lulu bapakna puang Budding. Penerusna petta Riu na Petta Lulu. iyaro Petta Tancca'nenek pole puang Jabbar Kepala Desa pa'mula di Desa Bontomacinna, maka seddi, Karaeng Pancce' bapak pole Karaeng Jabbar alena punna galung maloang nasaba pabbere pole tama toang na'. Karaeng Jabbar iya ro pammarenta di Desa Bontomacinna. Nasaba maega tau matau' dialena ka anggotana mewai penjajah tempona zaman penjajahang. Modele pamarentahanna Bontomacinna iya ro' pole ambenna no' di ana' na lettu cucunna. Maka dua Puang H. Ape' anak pole Puang Jabbar, bapak pole puang H. Iccu' (H. A. Mulhaeriddin Djabbar, S.Ag). alena kepala Desa Bontomacinna makkokoe' . jari Karaeng punna galung maega carana naulle maduntu suara (menang), tambah narekko keturunan Karaeng to na manccaji colon, ka iya ro Karaeng'e nafikkiri maega mo paggalung na nasuro mappile' calon Bupati na dukunge."

[Keturunan Karaeng yang dimaksud disini keturunan dari Petta Riu yang merupakan Karaeng dari kerajaan Bone dan salah satu keturunan Karaeng yang begitu besar yang ada di Bulukumba, beliau juga merupakan seseorang yang memiliki lahan pertanian terluas di Bulukumba yang diwariskan kepada anaknya bernama Petta Lulu, bapak dari puang Budding. Pertama keturunan dari penerus petta Riu dan Petta Lulu yaitu Petta Tancca'nenek dari Puang Jabbar yang merupakan kepala Desa pertama di Desa Bontomacinna, dan Karaeng Pancce' adalah bapak dari Karaeng Jabbar beliau juga merupakan pemilik lahan pertanian yang terluas karena warisan dari orang tuanya. Karaeng Jabbar adalah sosok pemimpin yang disegani oleh masyarakat karena keberaniannya melawan penjajah sehingga model kepemimpinan yang ada di Desa Bontomacinna bisa dikatakan Dinasti (turun temurun). Kedua Puang H. Ape' anak dari Puang Jabbar dan bapak dari Puang H. Iccu' (H. A. Mulhaeriddin Djabbar, S.Ag). Beliau adalah kepala Desa Bontomacinna yang sekarang. Sehingga
Karaeng sebagai pemilik lahan pertanian memilih pasangan tersebut dan berpotensi mendapatkan suara terbanyak karena selain sama-sama keturunan Karaeng para pemilik lahan pertanian tersebut memiliki banyak buruh tani yang bisa ikut memilih calon Bupati yangmereka dukung.] ${ }^{25}$

Dari hasil wawancara penulis dapat dikatan bahwa keberadaan Karaeng sebagai pemilik lahan pertanian berawal dari asal-usul mereka yang awanya mereka benar-benar dari keturunan Karaeng yang diwariskan lahan pertanian yang luas oleh nenek dan ayahnya sehingga para buruh tidak bisa berbuat apa-apa dan mereka lebih memilih untuk ikut dengan apa yang diinginkan atau yang dianjurkan oleh Karaeng tersebut karena hanya dengan cara kerjasama seperti inilah yang bisa membuat mereka tetap bekerja dan berpenghasilan untuk memenuhi kebutuhanya meskipun haknya sebagai pemilih yang bebas mennetukan pilihan di batasi.

Adapun hasil wawancara yang dilakukan peneliti terkait dengan Karaeng dan Buruh Tani dalam Pilkada 2015 dengan informan yakni Bapak Sahering kerjasama buruh tani dan hak pilih yang dibatasi oleh para Karaeng pemilik lahan pertanian.

“ Maega tau tea diisseng kedda' dibatasi hak pilihna, aro petani e maccoe mi bawang mi pilihanna Karaeng e iyya najamae' galungna ka matauki di alaiyyang galung na jamae', narekko kerjasama di pertanian antara buruh tani na Karaeng macole mo ka sistem na pake bagi hasi iya ro bage dua"

[Banyak orang tidak ingin diketahui bahwa dibatasi hak pilihnya, para buruh mengikut saja pada pilihan Karaeng tempat mereka bekerja sawahnya. Karena mereka takut apabila lahan tempat mereka bekerja akan diambil oleh Karaeng sebagai pemilik lahan, tetapi mengenai hubungan kerjasama antara buruh dan Karaeng terjalin dengan baik kerena sistem bagi hasil yang ditetapkan para Karaeng adalah hasil panen di bagi dua.] ${ }^{26}$

Dari hasil wawancara diatas dapat dikatakan bahwa benar adanya apabila saat ini hak pilih para buruh dibatasi oleh keberadaan Karaeng sebagai pemilik lahan pertanian karena adanya ketakutan para petani untuk protes secara langsung untuk tetap mempertahankan hak pilihnya sehingga meraka

${ }^{25}$ Hj.Bukke (106 Tahun, Tokoh Masyarakat Sekaligus Veteran Desa Bontomacinna), wawancara yang berlangsung pada hari Kamis, 30 Maret 2017, di kediaman Beliau di Desa Bontomacinna, Pukul 20.00 Wita.

${ }^{26}$ Sahering (57 Tahun, Buruh Tani ), wawancara yang pada hari Senin 17 April 2017, di kediaman Beliau di Desa Bontomacinna, Pukul 16.00 Wita. 
terpaksa harus mengikuti pilihan para Karaeng karena dengan harapan tetap memiliki mata pencaharian atau tetap bekerja dilahan tempat mereka bekerja.

Penjelasan yang sama diberikan oleh Udin. Adapun hasil wawancara yang dilakukan peneliti terkait dengan Karaeng dan buruh tani dalam pilkada 2015 dengan informan yakni bapak Udin yang mengatakan bahwa:

"Hubungan tolong menolong anatara Karaeng dan buruh tani adalah alasan kenapa Karaeng memerlukan buruh dalam menggarap sawahnya sehingga buruh juga tertarik dan bersemangat ketika mereka diberikan pekerjaan menjadi buruh di lahan milik Karaeng itu, supaya bisa memenuhi kebutuhan sehari-hari. Tetapi hubungan tolong menolong yang terjadi di Desa ini sudah berubah tidak sebatas buruh saja, tapi biasanya juga pekerjaan seperti mengecat rumah, membersihkan halaman, dan lain-lain.Karaeng meminta buruh untuk melakukannya, Sama juga ketika ada pemilihan para buruh tani di sini di himbau agar memilih calon yang didukung oleh Karaeng tempat ta bekerja". ${ }^{27}$

Dari hasil wawancara penulis dapat mengatakan bahwa dalam hubungan kerjasama antara Karaeng dan petani yang ada di Desa Bontomacinna bukan sekedar hubungan kerjasama seperti jadi buruh tani yang harus bekerja di sawah saja untuk memenuhi kehidupan melainkan adanya hubungan tolong menolong antar keduanya para buruh pun mau tidak mau akan memeberikan jasanya untuk Karaeng. Ini terjadi karena tidak adanya perjanjian sebelum melakukan hubungan kerjasama sehingga terjalin hubungan kerjasama tersebut.

\section{Hubungan Karaeng dan Buruh Tani Pasca Pilkada}

Pola relasi rakyat dengan pemimpin di Sulawesi Selatan banyak digambarkan sebagai pola hubungan patron klien dalam bahasa Bugis biasa disebut ponggawa. Hubungan patron klien tersebut terjalin secara sukarela dan hanya berdasarkan kontrak tertulis. Hubungan ini bisa berakhir kapan saja sepanjang klien tidak memiliki hutang kepada patronnya. Ia setiap saat bisa berpindah ke patron lain. Pemimpin juga dapat memberhentikan pengikutnya ketika ia tidak memenuhi kewajibannya. 28

\footnotetext{
27 Udin, (55 Tahun, Buruh Tani ), wawancara yang berlangsung pada Senin, 17April 2017, di kediaman Beliau, Pukul 16.00 Wita.

${ }^{28}$ Sitti, h 185
}

Hubungan yang terjalin antara Karaeng dan Buruh Tani pasca Pilkada masih tetap hubungan kerjasama antara keduanya yang saling membutuhkan satu sama lain. Tetapi hubungan ini tidak terjadi kepada semua para buruh dan Karaeng, hanya sebahagian saja yakni yang ikut memilih calon yang didukung oleh Karaeng.

\section{Memperbarui Hubungan Karaeng dan Buruh Tani}

Hubungan kerja sama yang berlaku di Desa Bontomacinna antara Karaeng pemilik lahan pertanian dan buruh tani, dimana buruh tani selalu mengikuti yang diperintahkan oleh Karaeng, khususnya hak pilih para buruh yang dibatasi karena mereka harus memilih calon Bupati yang didukung oleh Karaeng sebagaipemilik lahan.

Hubungan kerjasama antar Karaeng dan buruh tani yaitu hubungan timbal balik dimana Karaeng sebagai pemilik lahan pertanian membutuhkan buruh tani untuk menggarap sawahnya dan sebaliknya buruh tani membutuhkan pekerjaan. Namun ketika salah satu buruh tidak ingin dibatasi hak pilinya mereka nekat untuk tidak mengikuti himbauan Karaeng tempat mereka bekerja tetapi dengan resiko mereka harus kehilangan pekerjaannyaa sebagai buruh tani di tempat tersebut. Dan untuk memperbaiki hubungan yang pernah rusak karena pemilihan ketika beberapa tahun berlalu maka hubungan itu akan kembali baik dengan memberikan pekerjaan kembali kepada keluarga buruh atau anaknya. Sehingga begitulah yang terjadi terus-menerus.

\section{PENUTUP}

Mekanisme kehidupan politik dan sosial- budaya saling terkait di Desa Bontomacinna. Dimana hubungan kerjasama dengan mata pencaharian dan politik (pemilihan umum) selalu disangkutpautkan. Kandidat yang dipilih Karaeng sebagai pemilik lahan pertanian berpotensi mendapatkan suara terbanyak karena selain sama-sama keturunan Karaeng para pemilik lahan pertanian tersebut memiliki banyak buruh tani yang bisa ikut memilih calon Bupati yang mereka dukung.

Para buruh tidak memiliki pilihan lain kecuali mengikuti himbauan tersebut meskipun mereka sadar bahwa hak pilih mereka sudah dibatasi oleh keberadaan Karaeng, mereka tidak bisa berbuat apa-apa karena terikat dengan hubungan kerjasama. Menurut peneliti, hal ini dapat dikaitkan dengan hubungan patron klien yang terjadi di Indonesia 
dimana ada perbedaan antara patron dan klien karena sebagaimana yang di ketahui bahwa patron memiliki hak penuh atas apa yang mereka miliki namun klien harus mengikuti keputusan patron.

Masalah bagi para buruh tani ialah sistem bagi hasil. Meskipun sistem bagi hasil yang berlaku di Desa Bontomacinna itu bagi dua hasil panen. Tetapi mengenai pengadaan bibit, pupuk, pestisida di tanggung oleh buruh Tani sendiri. Karena hasil bagi dua diluar biaya penggarapan. Dan mengenai tunjangan yang dimaksud Karaeng yaitu mereka memberikan pinjaman berupa uang kepada buruhnya untuk biaya penggarapan dan di bayar saat selesai panen. Hal itu memberatkan para buruh dan menginginkan agar biaya penggarapan sawah ditanggung bersama agar sistem bagi hasil benarbenar bagi dua antara Karaeng dan buruh tani agar terjalin hubungan kerjasama yang menguntungkan kedua belah pihak.

Maka dari itu pula peneliti dapat memberikan dua kesimpulan yang pertama,bahwa para buruh tani tidak dapat melakukan perlawanan dengan membicarakan masalah dan solusi tentang hak pilihnya yang dibatasi oleh Karaeng sebagai pemilik lahan kepada pemerintah setempat (Kepala Desa). Kedua bahwa para buruh tani tidak mempunyai kekuatan atau keberanian untuk melakukan perlawanan karena masalah ini menyangkut pekerjaan dan mata pencaharian.

$$
* * *
$$

\section{DAFTAR PUSTAKA}

Ade Setiawan, “Gerakan Serikat Buruh Dengan Penolakan Batasan Hak Pilih (Studi Serikat Buruh Di Kabupaten Gresik Tahun 2011)", Skripsi (Gresik: fakultas Ilmu Sosial Dan Ilmu Politik, Universitas Gresik, 2014).

Andriani Saputri, "Patron Klien Antara Pemilik Lahan Dan Buruh Tani Studi Pada Desa Sipangan Bolon Kec. Girsang Bolon Kab. Simalungun", Skripsi, ( Medan: Jurusan Ilmu Sosial Politik, Fakultas Ilmu Sosial Dan Politik, 2015).

Haboddin Muhtar, "Karaeng Dalam Pusaran Politik Studi Kasus Di KabupatenJeneponto", Skripsi (Yogyakarta: Fakultas Ilmu Sosial Dan Ilmu Politik, Universitas Gajah Mada, 2009).
Heddy Shri Ahimsa Putra, Patron Dan Klien Di Selawesi Selatan Sebuah Kajian Fungsional Struktural, (Yogyakarta: KEPEL PRESS, 2007).

James C.Scott, Moral Ekonomi Petani Pergolakan Dan Subsistensi Di Asia Tenggara, (Jakarta: LP3ES, 1983).

Juanda Nawawi, "Strategi Kelompok Bangsawan Era Pemilihan Kepala Daerah Secara Langsung Oleh Rakyat Di Eks Kesultanan Buton 2014", Jurnal Analisis, Vol 3 No 3 (Desember 2014).

Lisa Harrison, Metodologi Penelitian Politik, (Jakarta: Kencana, 2009).

Rustinsyah, "Hubungan Patron-Klien Di Kalangan Petani Desa Kebonrejo Tahun 2011”, Jurnal Patron-Klien, Vol 2 No 1 (April 2014).

Sitti Zuhro, Demokrasi Lokal Perubahan Dan Kesinambungan Nilai-Nilai Budaya Politik Loka Di Jawa Timur, Sumatera Barat, Sulawesi Selatan, (Yogyakarta: Ombak 2009).

Sunyoto Usman, Sosiologi; Sejarah, Teori dan Metodologi, (Yogyakarta: Center for Indonesian Research and Development [CIReD], 2004).

Soerjono Soekanto, Sosiologi Suatu Pengantar, (Jakarta: Rajawali,1982).

Taufik Ahmad,"Genealogi Konflik Agraria Di Polongbangkeng Takalar", Jurnal Masyarakat Indonesia, Vol 4 No 2 (Desember 2014).

\section{Wawancara}

Abd. Hakim (45 Tahun, Buruh Tani), wawancara yang berlangsung pada hari Sabtu, 15 April 2017, di kediaman Beliau di Desa Bontomacinna, Pukul 16.00 Wita.

Abu Nawas (47 Tahun, Buruh Tani), wawancara yang berlangsung pada hari Senin, 17 April 2017, di Pabrik Padi di Desa Bontomacinna, Pukul 15.30 Wita.

H. A. Haerudding, (52 Tahun, Tokoh Masyarakat ), wawancara yang berlangsung pada hari 
Kamis, 30 Maret 2017, di kediaman Beliau di Desa Bontomacinna, Pukul 15.00 Wita.

H. A. Najamuddin. MBA, (51 Tahun, Karaeng), wawancara yang berlangsung pada hari Minggu, 02 April 2017, di kediaman Beliau di Desa Bontomacinna, Pukul 15.00 Wita.

Hj. A. Nimrah S. Pd, (44 Tahun,Karaeng), wawancara yang berlangsung pada hari Rabu, 05 April 2017, di kediaman Beliau di Desa Bontomacinna, Pukul 15.00 Wita.

H. A. Mulhaeriddin Djabbar, S.Ag, (37 Tahun, Kepala Desa Bontomacinna), wawancara yang berlangsung pada hari Sabtu, 01 April 2017, di kediaman Beliau di Desa Bontomacinna, Pukul 16.30 Wita.

H. A. Ratna, ( 56 Tahun, Karaeng), wawancara yang berlangsung pada hari Minggu, 02 April 2017, di kediaman Beliau di Desa Bontomacinna, Pukul 16.00 Wita.

Hj. Bukke (106 Tahun, Tokoh Masyarakat Sekaligus Veteran Desa Bontomacinna), wawancara yang berlangsung pada hari Kamis, 30 Maret 2017, di kediaman Beliau di Desa Bontomacinna, Pukul 20.00 Wita.

Sahering (57 Tahun, Buruh Tani ), wawancara yang pada hari Senin 17 April 2017, di kediaman Beliau di Desa Bontomacinna, Pukul 16.00 Wita.

Udin, (55 Tahun, Buruh Tani ), wawancara yang berlangsung pada Senin, 17April 2017, di kediaman Beliau, Pukul 16.00 Wita.

\section{Website}

http://kbbi.web.id/kooptasi.html, diakses pada tanggal 11/07/2017 Pukul 09.30 Wita. 